\title{
LA DIPUTACIÓN PROVINCIAL $Y$ LOS AYUNTAMIENTOS DE NUEVA ESPAÑA EN LA CONSUMACIÓN DE LA INDEPENDENCIA (1820-1821)
}

\author{
THE PROVINCIAL DEPUTATION AND THE \\ CITY COUNCILS OF NEW SPAIN IN THE \\ CONSUMMATION OF INDEPENDENCE \\ (1820-1821)
}

\author{
María del Carmen Salinas Sandoval \\ El Colegio Mexiquense, A.C. \\ csalinas@cmq.edu.mx
}

\begin{abstract}
At the end of the viceregal regime of New Spain, social actors, government institutions, ecclesiastical, military and civil authorities participated in building a new nation. This article shows the performance of the Provincial Deputation and the disturbance of lifestyle in municipalities, in the months prior to the consummation of Independence. We start from the premise that the liberal postulates emanating from the Political Constitution of the Spanish Monarchy (1812) -which marked political structure of the provinces- made it possible for these institutions to seek to maintain governance and fulfill their obligations and powers, despite the warlike atmosphere.
\end{abstract}

Keywords: Independence of Mexico, Provincial Council, City Council, Political Constitution of the Spanish Monarchy.

\section{Resumen}

Al término del régimen virreinal de Nueva España participaron actores sociales, instituciones de gobierno y autoridades eclesiásticas, militares y civiles para construir una nueva nación. Este artículo muestra el desempeño de la Diputación Provincial y la alteración de la vida de los ayuntamientos, en los meses previos a la consumación de la Independencia. Partimos de la premisa que los postulados liberales emanados de la Constitución Política de la Monárquica Española (1812), que marcaban la estructura política de las provincias, posibilitaron que estas instituciones estrechamente unidas buscaran mantener su gobernabilidad y cumplir con sus obligaciones y facultades, pese al ambiente bélico.

Palabras clave: Independencia de México, Diputación Provincial, Ayuntamiento, Constitución Política de la Monárquica Española. 


\section{Introducción}

El objetivo de este artículo es mostrar el desempeño de la Diputación Provincial y la alteración de la vida de los ayuntamientos de Nueva España, en los meses previos a la consumación de la Independencia de México (julio de 1820-septiembre de 1821). Partimos de la premisa que los postulados liberales emanados de la Constitución Política de la Monárquica Española (1812), que marcaban la estructura política de las provincias, posibilitaron que estas dos instituciones del gobierno español (diputación y ayuntamiento) buscaran mantener su gobernabilidad rechazando las medidas que contradecían esos postulados, pese al ambiente bélico de la última etapa del movimiento de Independencia; con lo cual apoyaron indirectamente el movimiento que impulsaban Agustín de Iturbide y el Ejército Trigarante.

En el proceso de la consumación de la Independencia, que terminó con el régimen virreinal e inició con la construcción de la nación mexicana, participaron diferentes actores sociales, instituciones de gobierno y autoridades eclesiásticas, militares y civiles. Entre ellos destacamos en este trabajo la participación de la Diputación Provincial y de los ayuntamientos constitucionales de Nueva España, sin pretender profundizar en la red de importantes relaciones entre los otros grupos sociales. Nuestro interés es contestar la siguiente pregunta: ¿̇cuál fue el papel de la Diputación Provincial y el de los ayuntamientos de Nueva España como dos instituciones liberales de la monarquía española en la culminación del movimiento de Independencia? Proponemos acercarnos a la última etapa del movimiento de Independencia apreciando la base de la estructura política dispuesta por la Constitución de Cádiz, a través de dos instituciones.

Entre las diferentes interpretaciones sobre la consumación de la guerra de Independencia, destacan tres corrientes historiográficas: la que considera que la consumación fue un hecho reaccionario, porque contrasta con los objetivos iniciales promovidos por los insurgentes Miguel Hidalgo y José Ma- ría Morelos;' la que la estudia bajo lupa las alianzas entre grupos de poder, como los criollos militares, sobresaliendo la labor de Iturbide; ${ }^{2}$ y la tercera expone la consumación como el final de un proceso que inició con la demanda de libertad de independencia en $1810 .{ }^{3}$ Las variadas interpretaciones señalan, en su mayoría, la importancia de los sucesos políticos y militares en un ámbito territorialmente amplio durante la culminación del movimiento de Independencia; por ello resaltamos los escasos estudios sobre las respuestas e intervenciones de las instituciones regionales y locales, como las diputaciones provinciales y los ayuntamientos (Serrano Ortega, 2014 y 2017).

El texto está dividido en cinco apartados: el alcance y el ambiente bélico avivado por el Ejército Trigarante en la consumación de la Independencia; las obligaciones y facultades liberales de las diputaciones y de los ayuntamientos, que fueron utilizadas contra las arbitrariedades de comandantes generales y de provincia de las fuerzas armadas virreinales y del jefe político superior; la instalación de la Diputación Provincial de Nueva España; la relación de la Diputación con el jefe político superior y capitán general; y la relación de la Diputación con los ayuntamientos.

\section{El Ejército Trigarante}

En 1820, después de una década de lucha, las fuerzas armadas del gobierno virreinal se encontraban dispersas y exhaustas, debido a la crisis financiera de la hacienda real y de los impuestos, así como a las dificultades de la administración y de la disciplina militar; por otro lado, las tropas independentistas encabezadas por Vicente Guerrero tenían mayor desgaste por haber mantenido en algunas zonas las guerrillas, con carencia de

1 Entre los autores de la primera corriente: Villoro (1981) y Lemoine (1985).

2 Entre los autores de la segunda corriente: Hamnett (1990), Ortiz (2008 y 1997) y Robertson (2012).

3 Entre los autores de la tercera corriente: Timothy (1981), Rodríguez (2009), Frasquet (2010), Moreno Gutiérrez (2016) y Del Arenal Fenochio (2002). 
recursos y con la destrucción de la agricultura (Archer, 2010: 153-154). Con la suma de ambas tropas se formó el movimiento Trigarante, que triunfó sin enfrentamientos mayores, pero sus luchas ofensivas contra los poblados y los militares renuentes a sus ideales provocaron la continuación del ambiente bélico en Nueva España (Moreno Gutiérrez, 2016: 381). En ese año, el enfrentamiento entre ambas fuerzas no ponía en riesgo la existencia política de las provincias, pero "sí trastornaba de muchos modos el funcionamiento cotidiano de algunos sectores sociales" (Moreno Gutiérrez, 2016: 380).

El Plan de Iguala, elaborado y promovido por Agustín de Iturbide en febrero de 1821, que defendía religión, independencia y unión, representó los intereses de grupos políticos y de poder de la ciudad de México, Veracruz, Puebla y Guadalajara; que durante la década de la guerra habían perdido parte de su poder político y económico y de su riqueza.

Agustín de Iturbide garantizó en el Plan la ciudadanía a todos los habitantes del Imperio sin distinción; no modificó la forma de gobierno, sólo buscaba una reforma pacífica; reconocía la independencia de Nueva España, pero al mismo tiempo otorgaba a Fernando VII el derecho de gobernarla o de enviar a uno de sus descendientes; y reconocía como única religión la católica ratificando los derechos y privilegios del clero. Se trató de organizar una revuelta para finalizar el movimiento de Independencia, mediante un plan político-militar, que aglutinara en un Ejército Trigarante a jefes y tropas del gobierno imperial y de los insurgentes (Ortiz Escamilla, 2014: 247-249).

El Ejército Trigarante se formó de una diversidad de grupos milicianos y militares, que encontraron en el Plan de Iguala la posibilidad de alcanzar un lugar destacado en el poder local o provincial, como las comandancias, que la cerrada estructura del virreinato lo había impedido. Con ello, las fuerzas trigarantes mantendrían las dinámicas de poder que habían generado en las zonas que dominaban por la lucha armada. Iturbide ordenó a los comandantes en las
Instrucciones Generales para los Comandantes de División, de marzo de 1821, que conservaran el orden en los pueblos de su zona jurando la Independencia, respetando a sus ciudadanos y propiedades, y convenciendo a los ayuntamientos que serían respetados de acuerdo con la Constitución de Cádiz (Del Arenal Fenochio, 2010: 143-144). A Iturbide le interesó mantener, mediante pactos, la paz en los pueblos y reconocer la autoridad política de los ayuntamientos, que buscó atraer a su causa.

El movimiento Trigarante fue un proceso bélico, porque contaba con mecanismos de guerra para ocupar militarmente ciudades, villas y fuertes. Se establecía el sitio de la plaza y se buscaban acuerdos con las autoridades civiles (principalmente ayuntamientos), eclesiásticas y funcionarios. Llegaban a acuerdos locales, como las condiciones en que se realizaría la evacuación, el respeto a la propiedad, al vecindario y a las autoridades, y la imposición de contribuciones especiales. Iturbide y sus oficiales sustituían con mayor frecuencia los discursos por las armas, para expandir su movimiento (Moreno Gutiérrez, 2016: 258). ${ }^{4}$

Además de las tácticas de guerra para atraer a la causa independentista, el Ejército Trigarante se enfrentó en varias ocasiones al ejército del gobierno, particularmente de marzo a agosto de 1821. Los datos oficiales del gobierno manifestaron que hubo 170 muertos de su ejército, provocando al enemigo 1400 muertos; y los Trigarantes informaban que tuvieron entre 170 y 190

4 El movimiento Trigarante se extendió en varios lugares de las provincias que formaban la Diputación de Nueva España, entre febrero y octubre de 1821: provincia de México (Iguala, Acapulco, San José del Río, Querétaro, Tulancingo, Pachuca, Zimapán, Huejutla, México); provincia de Oaxaca (Teotitlán, Tezoatlán, Huajuapan, Yanhuitlán, Oaxaca, San Ildefonso Villa Alta, Jicoyán); Provincia de Michoacán (Zitácuaro, Purúandiro, Maravatio, Tlalpujahua, Tajimaroa, Ario, Tecámbaro, Turicato, Apatzingán, Valladolid, Acámbaro); provincia de Veracruz (Perote, Orizaba, Córdoba, Alvarado, Xalapa, Boquilla de Piedras, Tantoyuca, Ozuluama, Tuxpan, Veracruz, Acayucan, Coatzacoalcos, Perote); provincia de Tlaxcala (Tlaxcala); y provincia de Puebla (Zacatlán, Huachinango, Tochimilco, Tlapa, Tepeaca, Tlatlauqui, Cholula, Puebla) (Moreno Gutiérrez, 2016: 268-276). 
muertos propios y 1090 a las filas enemigas (Moreno Gutiérrez, 2016: 233).

En agosto de 1821, los lugares que mantenían fidelidad a la Corona eran muy pocos; la mayoría de las provincias y pueblos no oponía resistencia al avance trigarante. En este mes llegó a Nueva España Juan de O’Donojú, nombrado por el rey Fernando VII para ocupar el cargo de jefe político superior y capitán general de la Nueva España; pero ante la generalización de apoyos al Plan de Iguala, firmó con Iturbide los Tratados de Córdoba. Como consecuencia, el objetivo de Iturbide se concentró en la capital de la provincia de Nueva España, organizando una estrategia militar con sus principales oficiales.

En junio de 1821, los realistas declararon inepto al Jefe Superior y Capitán General de Nueva España Juan Ruiz de Apodaca, Conde del Venadito, y algunos jefes militares resolvieron destituirlo quedando el mariscal de campo Francisco Novella como encargado del mando militar y del gobierno de Nueva España (Herrejón Peredo, 2007: 365). ${ }^{5}$ En un primer momento se negó a reconocer la legítima autoridad de Juan O’Donojú, pero para evitar un enfrentamiento entre los Trigarantes y las fuerzas del gobierno rindió pleitesía al jefe superior político, con una activa mediación de la Diputación y el Ayuntamiento de la ciudad de México, y O’Donojú logró la entrada del Ejército Trigarante a la ciudad de México, el 27 de septiembre de 1821, comandada por Iturbide.

El papel del Ejército Trigarante fue decisivo en la consumación de la Independencia bajo la dirección de Agustín de Iturbide, quien logró unir momentáneamente a los diferentes grupos políticos y militares en torno al Plan de Iguala. El triunfo de los trigarantes estuvo acompañado de la afectación de otros grupos sociales y de instituciones, que participaron en ese proceso, directa e indirectamente. Entre ellas se encuentran las diputaciones provinciales y los ayuntamientos constitucionales, en cuyas manos se encontraba el gobierno político y económico local y regional, particularmente en

5 Sesión 11 extraordinaria, 6 de julio de 1821.
Nueva España, centro del avance Trigarante y de la capital del virreinato. La etapa final de la lucha por la Independencia no puede explicarse sin la ideología liberal y los mandatos constitucionales de 1812. Juan Ortiz Escamilla expone la importancia de las diputaciones y ayuntamientos en la culminación del proceso:

Entre 1820 y 1825 el fenómeno multiplicador, tanto de diputaciones provinciales como de ayuntamientos en los antiguos territorios coloniales, significó la culminación del proceso revolucionario iniciado en 1810 [...] aun cuando la mayoría de las poblaciones contaba con fuerzas armadas, otra vez fue necesaria la participación de las élites regionales y locales representadas en los ayuntamientos y en las milicias (Ortiz Escamilla, 2014: 246).

Exponemos a continuación las bases legales de la actuación liberal de las diputaciones y de los ayuntamientos para posteriormente atender la creación de la Diputación Provincial de Nueva España y su relación, por una parte, con el capitán general del antiguo virreinato de Nueva España y jefe político superior de la provincia de Nueva España (virrey durante la monarquía absoluta) y, por otra, con algunos ayuntamientos constitucionales de esa provincia.

\section{Obligaciones y facultades liberales de diputaciones y ayuntamientos}

La Constitución Política de la Monarquía Española de 1812 fue un documento que transformó las relaciones políticas del Imperio español, tanto en América como en Europa. Buscaba crear un Estado unitario con todas las partes de la monarquía española. A partir de sus postulados, los diputados a las Cortes se declararon representantes de la Nación y la soberanía quedó dividida en tres niveles: las Cortes representaban la soberanía nacional, la diputación provincial la soberanía de la provincia y el ayuntamiento la soberanía municipal, que se legitimaba por los procesos electorales (Chust Calero, 2007: 47). Con la creación de instituciones, 
como las Cortes, las Diputaciones Provinciales y los ayuntamientos, se inició una revolución política (Rodríguez, 2007: 364-365).

Las dos nuevas instituciones (diputaciones provinciales y ayuntamientos) reorganizaron el territorio de la monarquía moderada hispánica en dos niveles: la provincia y los pueblos, dos espacios administrativos territoriales que los ejércitos en pugna durante la guerra de Independencia en Nueva España consideraron fundamentales. Esto se debió, de acuerdo con Pérez Garzón, a que se escalonó el control del poder desde los ayuntamientos, estableciendo un concepto centralizador que impusieron los liberales bajo la supervisión de la diputación provincial; no obstante, las competencias municipales fueron diversas y novedosas, convirtiendo la política local en un eslabón esencial para la conservación del orden y para la recaudación de contribuciones en la provincia (2007: 360-361).

La Constitución gaditana y las Instrucciones para el gobierno económico-político de las provincias establecían que el gobierno de cada provincia estaría a cargo de una Diputación compuesta por el jefe político superior (responsable del gobierno de la provincia nombrado por el rey), el intendente (nombrados por el rey) y siete personas (elegidas por los ciudadanos de manera indirecta), con la misión de promover la prosperidad de la provincia y fomentar sus intereses económicos. La diputación provincial respondía al gobierno nacional de España de manera directa, y a través de su jefe político; era un organismo de administración con una amplia responsabilidad en materia de supervisión. Una de sus principales tareas era "cuidar el establecimiento de ayuntamientos" en aquellos pueblos con más de mil almas; se le asignó la labor de supervisar a los ayuntamientos en los rubros de impuestos y gastos, salud, justicia y obras públicas, y de asegurarse que los pueblos establecieran escuelas primarias de letras. Este organismo también tenía la labor de resolver las disputas que pudieran generarse en los ayuntamientos, particularmente en lo referente a las finanzas. En el nivel pro- vincial, la diputación debía trazar los planes "para fomentar la agricultura, la industria, las artes y el comercio". También se le asignó la función de coordinar las obras públicas provinciales y nacionales. Para llevar a cabo estas empresas, la nueva institución debía organizar un censo y desarrollar estadísticas para la provincia (Cortes Generales y Extraordinarias, 1811, Tomo IV: 105-126).

Las disposiciones liberales decretadas en Cádiz estuvieron vigentes en Nueva España de mayo de 1813 a noviembre de 1814 y de marzo de 1820 a septiembre de 1823. En la primera etapa se acogieron con reserva las nuevas disposiciones liberales debido al desconocimiento que se tenía de ellas y a la situación bélica en algunas zonas; pero en la segunda etapa se impulsó con rapidez el establecimiento de los ayuntamientos, con la esperanza que la reinstalación de la Constitución terminara con los problemas económicos y el desorden sociopolítico, ocasionados por la larga lucha de los insurgentes.

Cuando Agustín de Iturbide entró a la ciudad de México el 27 septiembre de 1821, frente al Ejército Trigarante marcando el fin de la guerra de Independencia y el inicio de la vida independiente, siguieron vigentes las medidas liberales de la Constitución española adecuándose a los cambios impuestos por la reglamentación política de la monarquía de Iturbide. El Primer Imperio aprobó varias disposiciones gaditanas: la forma de gobierno monárquica, la división de poderes, la inclusión de los derechos del hombre, la supremacía de la ley y el establecimiento de ayuntamientos constitucionales y las diputaciones provinciales (Del Arenal Fenochio, 2010: 168; Salinas, 2011: 80).

La Constitución de Cádiz de 1812 contenía principios revolucionarios en la estructura política, como la igualdad jurídica entre los integrantes de la sociedad, la representación ciudadana y la libertad individual. Bajo el amparo de esas propuestas legales se crearon los ayuntamientos constitucionales en el antiguo virreinato de Nueva España, que fueron acogiendo una manera diferente de organizarse como administradores y gobernantes de los pueblos, haciendas y ranchos 
de su jurisdicción. Fue compleja la adopción de los elementos liberales, porque se fueron combinando con los usos y costumbres colectivos practicados durante casi tres siglos de gobierno colonial, tomando características especiales en cada región. Con ello se estableció la organización de los municipios, se consolidó su institución como instancia básica de gobierno, así como una organización territorial y poblacional, dando fin a las regidurías perpetuas y promoviendo la representación donde había repúblicas de indios (quedaron extinguidas), ayuntamientos de criollos y peninsulares y donde no los había (Cortes Generales y Extraordinarias, 1811, Tomo IV: 105-126).

El ayuntamiento se integraba por alcalde o alcaldes, regidores (elegidos indirectamente cada año), un procurador síndico, presididos por el jefe político superior donde lo hubiera Sus atribuciones eran atender los asuntos de salubridad, orden público, instrucción primaria, beneficencia, obras públicas, cárceles municipales y la recaudación e inversión de los caudales que administraban; estaban sujetas a la supervisión de los jefes políticos superiores y diputaciones provinciales (Luna Ramos et al., 2012: 165-170).

La política local empezó a comprender las primeras relaciones entre ciudadanos y su participación en la estructura gubernamental de tipo liberal por medio de los ayuntamientos. Éstos recurrieron con sus demandas directamente a la Diputación Provincial, como la autoridad de la cual dependía directamente el orden político administrativo de la Provincia.

Una mayor cantidad de ayuntamientos constitucionales empezó a estar presente en los distintos ramos de la vida política local y en las actividades públicas de la sociedad. Los ayuntamientos fueron adquiriendo lentamente legitimidad, como autoridades que eran elegidas por los ciudadanos y que los representaban en los asuntos políticos y económicos.

La legitimidad de los ayuntamientos se incrementó en aquellas localidades donde se convirtieron en transmisores ante la Di- putación de las calamidades ocasionadas durante el movimiento Trigarante.

La Constitución gaditana no sólo propuso una nueva división territorial y de poderes locales -supresión de las repúblicas de indios, cambio de jerarquía de pueblos sujetos que pasaron a ser cabecera e instalación de un ayuntamiento cada mil habitantes-, sino que implicó una nueva práctica electoral, que requirió la creación de instancias apropiadas para homologar la elección de todos los ayuntamientos y diputados, a través de la participación de los ciudadanos. La elección se hacía indirecta en tercer grado para elegir diputados provinciales y de cortes, a través de juntas parroquiales, de partido y de provincia.

Con la guerra de Independencia y las reformas gaditanas, el sistema fiscal local sufriría una serie de transformaciones que fragmentarían la incipiente organización hacendaria. La escena fiscal fue un asunto administrativo de trascendencia en el nuevo orden liberal. Durante la primera experiencia gaditana las haciendas locales gozaron de una cierta autonomía gracias al estado de guerra en muchos pueblos (1813-1814) y al aprendizaje de las nuevas normas; en cambio, los erarios de los ayuntamientos de 1820 y 1821, que se encontraban en territorios que empezaban a ser pacificados y que seguían estando dominados por los militares, sufrieron las carencias económicas y las cargas extraordinarias de guerra que los 10 años de revolución habían provocado (Salinas, 2007: 385).

Las dos instituciones caminaron juntas en el proceso de organizar la Provincia de Nueva España en un momento convulso dado por la última etapa del movimiento de Independencia. Es imprescindible visualizar la función de la Diputación y la de los ayuntamientos de manera articulada, ya que los segundos no podían tomar ninguna decisión definitiva sin contar previamente con la de la Diputación, en temas tan importantes como el orden público, la milicia cívica, las contribuciones y en todas las medidas referentes al gobierno político y económico de sus comarcas. (Salinas, 2011: 85). 


\section{La instalación de la Diputación Provincial de Nueva España}

Al amparo de la Constitución gaditana se organizaron territorial y administrativamente 19 diputaciones provinciales de ultramar: Nueva España, Nueva Galicia, Yucatán, San Luis Potosí, Provincias Internas de Oriente, Provincias Internas de Occidente, Guatemala, Nicaragua, Cuba con las dos Floridas, Santo Domingo y Puerto Rico, Nueva Granada, Venezuela, Quito, Perú, Cuzco, Charcas, Chile, Río de la Plata y las Filipinas (Rodríguez, 2007: 367).

Las siete provincias que componían la Nueva España fueron México, Puebla, Valladolid de Michoacán, Oaxaca, Veracruz, Tlaxcala y Querétaro; sus ciudadanos atendieron la convocatoria para la elección indirecta de sus diputados. Se llevaron a cabo las elecciones de parroquia, de partido y provincial para diputados ante las Cortes y la diputación provincial en el vasto territorio de la Diputación Provincial de Nueva España, empresa que resultó difícil. La Junta Preparatoria de esta diputación había dispuesto que cada una de las siete provincias en que se constituía, organizara sus propias elecciones de partido, parroquia y provincial, para los diputados ante las Cortes y la Diputación Provincial. Grandes zonas dentro de Michoacán y Veracruz estaban bajo el control parcial o casi total de los insurgentes, y las elecciones sólo podían llevarse a cabo en las áreas controladas por los realistas (Rodríguez, 2007: 379).

La Junta Preparatoria de la Diputación Provincial de Nueva España se reunió el 11 de noviembre de 1812, pero se instaló hasta el 13 de julio de 1814, celebrando su primera sesión el 18 de julio; 6 sin embargo, un mes

6 La Diputación Provincial de Nueva España debía estar conformada por siete diputados propietarios, tres suplentes, el jefe político superior -el virrey- y el intendente. De ellos asistieron "Félix María Calleja, jefe político; Román Gutiérrez del Mazo, intendente; José Ángel Gazano, diputado por México; Pedro Acevedo y Calderón, diputado por Querétaro; José Daza y Artazo, diputado por Tlaxcala; Juan Bautista Lobo, elegido por la provincia de México para que tomara el lugar del diputado de Oaxaca; e Ignacio García Illueca, suplente por México" (Benson, 1994: 48). después el virrey Félix María Calleja suspendió todo cambio gubernativo y el 5 de octubre de ese año un decreto real suspendía las diputaciones en América. El restablecimiento de la Constitución gaditana en marzo de 1820 permitió que la Diputación Provincial de Nueva España se reinstalara en julio de ese año hasta unos días después de la consumación de la Independencia (Benson, 1994: 42, 48-49). ${ }^{7}$

Los diputados de la Diputación de Nueva España sesionaron 21 ocasiones hasta septiembre de 1820, porque las disposiciones legales determinaban que tenían que renovarse sus integrantes. En este mismo mes empezó a funcionar la nueva diputación provincial; del 30 de septiembre de 1820 al 25 de septiembre de 1821 tuvieron un total de 102 sesiones, en las cuales atendieron 1250 asuntos (Herrejón Peredo, 1988: 198). ${ }^{8}$

Destacaron los asuntos referentes a los ayuntamientos (32\%), a la organización interna de la Diputación (9.6\%), a la tributación (7\%) y a los problemas por tierras de los pueblos (6.4\%) (Herrejón Peredo, 1988: 199-205). En sus resoluciones observó los principios liberales, de igualdad y ciudadanía, castigó el abuso de poder de los funcionarios y respetó la libertad de imprenta. Al debilitarse los lazos de la Nueva España con la metrópoli española, por la lucha independentista, permaneció la huella liberal que había producido la aplicación de la Constitución de 1812. Al igual que la Diputación, los ayuntamientos constitucionales tomaron con responsabilidad sus funciones

7 En julio de 1820 se reinstaló la Diputación de Nueva España con el Jefe Político de la Nueva España -Conde del Venadito-, el intendente Ramón Gutiérrez del Mazo, Pedro de Acevedo por Querétaro, Juan Bautista Lobo por México, José María Couto por Veracruz, José Julián Daza por Tlaxcala, José Ignacio García Illueca -suplente por México- y Francisco Pablo Vázquez por Puebla (Herrejón, 1988: 196-197).

8 En septiembre de 1820 se renovó la diputación provincial de Nueva España, quedando integrada por: el Jefe Político de la Nueva España Conde del Venadito, el intendente Gutiérrez del Mazo, Miguel Guridi y Alcocer por Tlaxcala, José María Fagoaga por México, Juan Wenceslao Barquera por Querétaro, Juan Bautista Lobo por Veracruz, Francisco Ignacio Mimiaga por Oaxaca, Patricio Furlong por Puebla (sustituido por José Ignacio García Illueca), y Juan Pastor Morales por Valladolid (Herrejón Peredo, 1988: 197-198). 
gubernativas y administrativas, actuando para promover el bienestar de sus ciudades, villas y pueblos (Herrejón Peredo, 1988: 195218).

A partir del restablecimiento de las normas gaditanas, en 1820, la Diputación de Nueva España tuvo un importante papel en la etapa de la consumación del movimiento de Independencia. La posición liberal de sus integrantes quedó expuesta en las resoluciones de los principales asuntos; que muchas veces se enfrentaron a las ideas y al proceder del jefe superior político. Con la defensa que hicieron, a los derechos liberales y a los postulados constitucionales, al resolver algunos asuntos apoyaron directa e indirectamente el avance de los trigarantes, como apreciaremos en el siguiente apartado.

Dividimos en dos las tareas donde se destacó la posición liberal constitucionalista de la Diputación Provincial de Nueva España: en su relación con el jefe político superior y capitán general, y en su relación con los ayuntamientos constitucionales. En las dos dejó evidencia de legitimidad gubernativa basada en la legalidad liberal, en un momento crucial para la finalización del movimiento de Independencia, que expuso medidas arbitrarias de la autoridad superior que representaba al rey y medidas que afectaron a los ayuntamientos.

\section{La Diputación Provincial de Nueva España y el jefe político superior y capitán general}

Un hecho relevante en la Provincia de Nueva España sucedió con el rompimiento entre el Jefe Político Superior Juan Ruiz de Apodaca, conde del Venadito, y la Diputación Provincial, el 31 de mayo de 1821; hecho que comprobaba el vigor adquirido por la Diputación para enfrentarse a la autoridad superior. Ésta acusó a Apodaca de violar la Constitución al suspender la libertad de imprenta para impedir la propagación ideológica de independencia del Ejército Trigarante. Una de las publicaciones que orillaron a Apodaca a adoptar esta medida fue un papel impreso titulado El hombre libre, pero entre bayonetas. El pliego de Apodaca dirigido a la Diputación exponía:

Antes de ayer y ayer se han impreso y publicado papeles en la imprenta de Alejandro Valdés, cuyos originales no dejan duda que son y dimanan del pérfido Iturbide, remitidos aquí para el efecto de imprimirse, de modo que no tiene necesidad de imprenta suya, pues se vale de las de esta capital para su seducción e ir arruinando la concordia entre individuos de la nación, fieles a la Constitución y al rey, y perder a todos para adelantar su proyecto despótico y anárquico [...] En este concepto y en el orden de otras particularidades que por no ser difuso omito, consulto si como parece estamos en el caso para la salvación de esta capital y reino de suspender, con arreglo al artículo 170 de la Constitución de la Monarquía Española, y a las leyes, todas las trabas políticas a lo menos por un mes, y la imprenta libre, como desea la parte sana de esta capital, según a cada momento lo vienen a solicitar de mí, sujetos de probidad y fidelidad de ella, cuya consulta hago a otras corporaciones y autoridades de esta ciudad, y a vuestra excelencia esperando que cite inmediatamente junta extraordinaria y me dirija su contestación con la urgencia que requieren las circunstancias (Herrejón Peredo, 2007: 343-344). ${ }^{9}$

La diputación acordó contestar que el artículo 170 de la Constitución, ${ }^{10}$ si bien declaraba que la autoridad del rey se extendía a cuanto condujera a la conservación del orden público y a la seguridad del Estado, luego añadía que debía ser conforme a la Constitución y a las leyes. De modo que todo lo que estaba dirigido a derogar lo establecido por la Constitución no entraba en las facultades del conde del Venadito. La Diputación agregó que la Constitución estaba íntimamente unida con la libertad de

9 Sesión 86 extraordinaria, 31 de mayo de 1821.

10 El artículo 170 de la Constitución de Cádiz establecía: "La potestad de hacer ejecutar las leyes reside exclusivamente en el Rey, y su autoridad se extiende a todo cuanto conduce a la conservación del orden público en lo interior, y a la seguridad del Estado en lo exterior, conforme a la Constitución y a las leyes" (Luna Ramos et al., 2012: 122). 
imprenta, tanto que se podía asegurar que era su "esencia y espíritu", y por eso entre las facultades de las cortes se asignó expresamente la de proteger la libertad política de imprenta.

Aun cuando el jefe político superior expusiera los recientes y frecuentes ejemplos del abuso de la libertad de imprenta, ya los habían previsto las cortes que aun así habían decidido establecerla. Sus vicios por perjudiciales que fueran eran menores en concepto de la Diputación que los males que amenazaban con su prohibición. Exhortaron al conde del Venadito a castigar a los infractores de la ley, quienes habían realizado "criminales abusos de la libertad de imprenta"; pero no era extinguiéndola como se sostendría el gobierno legítimo (Herrejón Peredo, 2007: 343-345). ${ }^{11}$

Otro asunto que enfrentó a ambas autoridades prosperó cuando el conde del Venadito manifestó en junio de 1821 a la Diputación Provincial que se le habían agotado los recursos económicos proporcionados por la Hacienda pública para hacer frente a todos los gastos nacionales; particularmente se consumieron después de la sublevación promovida por el "pérfido Iturbide", cuyo importe ascendía a 200,000 pesos. Por ello, acudía a la Diputación Provincial para que le proporcionara "los medios más equitativos y justos de tener numerario correspondiente para el pago que las urgentes necesidades del Estado" (Herrejón Peredo, 2007: 347-348). ${ }^{12}$ La Diputación acordó contestarle que eran lamentables las circunstancias en que se hallaba la provincia de Nueva España, con dificultades insuperables; pero no podía cubrir los gastos extraordinarios como los que se presentaban y no alcanzaban las contribuciones, porque los ingresos eran "lentos". Le explicó que se pediría a los prestamistas empréstitos bajo condiciones atractivas para ellos; sin embargo, como tales empréstitos solamente podían obtenerse de los ciudadanos solventes, a éstos habría que persuadir para lograr el dinero con la oportunidad requerida por la urgencia (Herrejón Peredo, 2007: 347-348). ${ }^{13}$

11 Sesión 86 extraordinaria, 31 de mayo de 1821.

12 Segunda sesión extraordinaria, 3 de junio de 1821.

13 Segunda sesión extraordinaria, 3 de junio de 1821.
Un asunto de suma importancia para todo el antiguo virreinato lo expuso el Jefe Político Superior de la Nueva España, Juan Ruiz de Apodaca, el 6 de julio; informó a la Diputación que entregaba "libremente el mando militar y político de estos reinos a petición respetuosa que me han hecho los señores oficiales y tropas expedicionarias, por convenir así al mejor servicio de la Nación, en el señor Mariscal del Campo Don Francisco Novella" (Herrejón Peredo, 2007: 365). ${ }^{14}$ Dos días después, Novella Azabal asumió el cargo de Jefe Superior Político de la Provincia de la Nueva España, después de una serie de discrepancias con la Diputación Provincial, ya que ésta consideraba nula la dimisión del conde del Venadito, así como la designación de Novella, porque se había quebrantado la Constitución (Herrejón Peredo, 2007: 23).

El 31 de agosto, la Diputación Provincial de la Nueva España, después de la asistencia de dos de sus representantes a una reunión convocada por el Jefe Superior Político Novella con las corporaciones civiles, eclesiásticas y militares, aprobó que Juan O’Donojú, reconocido por el rey como jefe político superior, pactara la Independencia con Agustín de Iturbide. Decisión contraria a la que habían mantenido Novella y el ejército expedicionario. Expuso la Diputación a Novella:

El suspender la efusión de sangre que se ha derramado con tanta abundancia y el procurar la paz a un reino agitado tantos años con la guerra civil más horrorosa son dos objetivos los más interesantes a su prosperidad y los mismos que lo logran con la transacción celebrada por el excelentísimo señor don Juan O’Donojú en Córdoba. Esto bastaba para decidirnos por su admisión y no sólo consultársela a vuestra excelencia, sino también pedírsela con insistencia, pero concurren otras consideraciones que la fundan y exigen su prontitud (Herrejón Peredo, 2007: 385-387). ${ }^{15}$

La Diputación agregaba a Novella que O’Donojú había sido nombrado por el rey

14 Sesión 11 extraordinaria, 6 de julio de 1821.

15 Sesión 18 extraordinaria, 31 agosto de 1821. 
para gobernar, como dictaba la constitución, había hecho el juramento y se había presentado ante la primera autoridad que encontró expedita, que fue la de Veracruz. Le criticó que hubiera expresado que "se privaba su gobierno de estar acorde con las ideas del señor O’Donojú". La Diputación informó a O’Donojú sobre estos acontecimientos, expresando sus plácemes por su llegada a Nueva España y por "las ideas benéficas a la humanidad con que desde luego se ha dado a conocer y estimar por todos estos habitantes”. Además de la afanosa participación de la Diputación, también participó el Ayuntamiento de la Ciudad de México, como veremos en el último apartado (Herrejón Peredo, 2007: 385-387). ${ }^{16}$

El 18 de septiembre Ramón Gutiérrez del Mazo, intendente de Nueva España, que era parte de la Diputación, informó a ésta que recibió un oficio de Juan O’Donojú, donde adjuntaba otro del ministro de gobernación de Ultramar, del 25 de enero, donde el rey lo nombraba como Capitán General de la Nueva España "con los mismos goces y distinciones de los virreyes y gobernadores, y para el mejor servicio del Estado español se conservaba unido el mando político y militar"; por lo que también lo nombraba Jefe Político Superior.

Con las atribuciones y facultades que le correspondían con arreglo a la Constitución de Cádiz y a los decretos e instrucciones de las Cortes, O’Donojú presentó ante el Ayuntamiento de la ciudad de México el juramento de guardar y hacer guardar la Constitución de Cádiz y observar las leyes (Herrejón Peredo, 2007: 389). ${ }^{17}$

Con este acto se confirmó el reconocimiento oficial de Juan O’Donojú como Capitán General de la Nueva España y Jefe Político Superior. El reconocimiento quedó en manos de las dos autoridades más importantes de Nueva España, en ese momento: la Diputación Provincial y el Ayuntamiento de la ciudad de México, y con esa aprobación se respaldaban los actos en favor de la consumación de la Independencia.

16 Sesión 18 extraordinaria, 31 agosto de 1821. 17 Sesión 20, 18 de septiembre de 1821.
La relación de la Diputación Provincial con el Ayuntamiento de la ciudad de México, así como con otros ayuntamientos, se apegó a lo dictado en la Constitución gaditana y en la Instrucción para el Gobierno Económico Político de las Provincias, resultando un trato de apoyo y entendimiento; no así con el conde del Venadito y con Novella.

\section{La Diputación Provincial de Nueva España y los Ayuntamientos}

En 1820, era evidente que los 10 años de la guerra de Independencia habían afectado las localidades de Nueva España, por los intermitentes levantamientos en su territorio; particularmente la zona sur y la que circundaba la ciudad de México se convirtieron en foro de principales batallas, muchas de ellas coordinadas por líderes locales que hacían uso de la guerrilla (Vicente Guerrero, Pedro Ascencio de Alquisiras) como táctica principal de lucha. Nueva España permaneció entre batallas, saqueos, represión y proclamas (Baranda y García, 1987, vol. 1: 43-84).

Como consecuencia de la guerra de Independencia, las dos principales instituciones derivadas de la Constitución liberal, ayuntamientos y diputación provincial encargadas del gobierno interior de la provincia de Nueva España trataron de mantener la estructura de la monarquía española al interior de la provincia; enfrentándose al descontrol militar que agobiaba a los ayuntamientos y a los pueblos, al aumento desproporcionado de contribuciones dirigidas a mantener los grupos militares y a la escasez de arbitrios que fortalecieran los ingresos municipales.

Las dos instituciones caminaron juntas en el proceso de organizar la provincia de Nueva España, resolviendo sus conflictos y utilizando sus pocos recursos, bajo el manto de la Constitución. La Diputación Provincial fomentaba la creación de ayuntamientos constitucionales para limitar las diversas células políticas que fomentaban insubordinación, para terminar con la intranquilidad pública provocada por la guerra de Independencia, y para atraer al orden cons- 
titucional a los cabecillas regionales que organizaban levantamientos sociales. ${ }^{18} \mathrm{~A}$ los pueblos que se habían sumado al movimiento de Independencia no los constituían con ayuntamiento.

Después de su erección, los ayuntamientos constitucionales hacían constantes demandas a la Diputación Provincial de Nueva España, de acuerdo con los cambios institucionales impuestos. El tipo de inquietudes demostraba que estaban asimilando los nuevos parámetros liberales que consideraban la participación ciudadana y la igualdad ante la ley. Buscaban aplicar las normas jurídicas, los principios liberales y sus facultades de gobierno (administración de justicia, policía, guerra y hacienda); pero se enfrentaban a una realidad alterada por la guerra y la ocupación militar, que modificaba sus pretensiones. A pesar de esta realidad, los ayuntamientos tuvieron una continuidad durante el periodo de consumación de Independencia, aunque se estuviera dando un resquebrajamiento de la monarquía española; de acuerdo con Juan Ortiz EscamiIla, "los órganos representativos locales se encontraban en pleno goce de sus facultades", en el periodo de consumación de la Independencia (1992: 196).

La capital del antiguo virreinato de Nueva España, la ciudad de México, no sufrió ofensivas durante el movimiento de Independencia, pero tuvo grupos que simpatizaron con el movimiento insurgente y trigarante, como los Guadalupes, que demostraron que las aspiraciones de autonomía criolla estaban difundidas en el espacio urbano capitalino; lo que significó un triunfo de los insurgentes en la ciudad sin un enfrentamiento abierto con el orden colonial (Guedea, 1992: 127-171). En 1808, el ayuntamiento, como el principal baluarte de los criollos, observó por la ausencia del poder real en España la posibilidad de lograr reformas

\footnotetext{
18 Juan Ortiz Escamilla narra la efectividad de la creación del ayuntamiento en las localidades de Paso de Ovejas y Puente del Rey, en diciembre de 1820, para controlar el descontento social: "se trataba de una maniobra política que sí funcionó, pues con la creación del primer ayuntamiento constitucional se restó partidarios a la revolución" (2010: 160).
}

políticas sin desconocer a la Corona, proponiendo un cambio en la forma de gobierno cuyo fundamento de la sociedad no fuera el rey sino los organismos constituidos, como los ayuntamientos. Una de sus principales propuestas consideraba que la verdadera representación popular se encontraba en los ayuntamientos. Se enfrentó a la Real Audiencia, donde se concentraban los funcionarios europeos nombrados por la Corona, quienes percibieron en las pretensiones del ayuntamiento de la ciudad de México el espíritu de independencia al querer igualar derechos en la Nueva España con los de la metrópoli (Villoro, 2000: 500-501). Esta actitud beligerante del ayuntamiento de la Ciudad de México continuó al constituirse en ayuntamiento constitucional, según la legislación de Cádiz.

A partir que los trigarantes encabezados por Agustín de Iturbide difundieron y distribuyeron el Plan de Iguala en febrero de 1821, el ayuntamiento de la Ciudad de México conservó una relación estrecha con la Diputación Provincial. Este acercamiento aconteció con menor frecuencia con otros ayuntamientos a partir de julio de 1821, porque la Diputación recibió pocos asuntos sobre ayuntamientos, debido a que el Ejército Trigarante ocupaba los caminos y no podían llegar los asuntos de otros lugares de la provincia a la ciudad de México. La Diputación informó al jefe político superior que, al estar interrumpidas las comunicaciones de las provincias con la capital, acordó suspender sus sesiones semanarias por la falta de asuntos que tratar, mediante la interrupción de las comunicaciones de las provincias (Herrejón Peredo, 2007: 371-372). ${ }^{19}$

Las tareas en las que estuvieron involucrados la Diputación Provincial y el ayuntamiento de la ciudad de México fueron determinantes para mantener la representatividad y gobernabilidad en Nueva España, dentro de un mundo amenazado por la insurrección militar. Uno de los principales asuntos en los que estuvieron involucrados fue el pliego dirigido al ayuntamiento de la ciudad de México por el coronel Agustín de

19 Sesión 14, 14 de julio de 1821. 
Iturbide, en marzo de 1821, presentándose como comandante general del sur y Temascaltepec, donde le exponía sus proyectos de Independencia contra la integridad de la monarquía. La Diputación manifestó en su nombre y en el del ayuntamiento que defenderían los fundamentos de la Constitución Política de la Monarquía Española ante la actitud beligerante de Iturbide:

Esta Diputación Provincial que por el sistema fundamental está establecida y constituida como la principal corporación a quien se haya encomendada la pública prosperidad y la corporación con vuestra excelencia para todo lo que contribuya al buen orden y tranquilidad que se advierte amenazada en las actuales circunstancias [...] Desde que tuvo las primeras noticias de las novedades ocurrentes, ha estado dispuesta a llenar todos los deberes de su instituto, y se ofrece de nuevo a coadyuvar en parte que le toque a cuantas medidas y providencias juzgue vuestra excelencia convenientes tomar para impedir los males políticos que amenazan y conservar la tranquilidad pública que nuestra Constitución le tiene encomendada (Herrejón Peredo, 2007: 261-263). ${ }^{20}$

La Diputación recibía permanentemente del jefe político superior los movimientos realizados por Iturbide. El conde del Venadito expuso que el coronel Iturbide se aproximaba a la capital "con gente de armas con el fin de atacarla", y estaba resuelto a impedirlo y evitar los desastres que seguirían si lograba sus hostiles y anticonstitucionales objetivos. La Diputación ratificó que coadyuvaría a la tranquilidad pública con el apoyo del ayuntamiento de la ciudad de México (Herrejón Peredo, 2007: 263, 264 y 275). ${ }^{21}$

El conde del Venadito indicó al ayuntamiento de la ciudad de México, en abril de 1821, que era muy urgente la formación de las milicias nacionales y que se perdería mucho tiempo en esperar la llegada del reglamento correspondiente con las "ritualidades ordinarias" de la metrópoli española.

20 Sesión 66, 3 de marzo de 1821.

21 Sesión 67, 6 de marzo de 1821 y Sesión 70, 17 de marzo de 1821.
La Diputación opinó lo contrario. Consideró que era necesario esperar el reglamento y observar lo dispuesto en la real declaración sobre puntos esenciales de la ordenanza de milicias provinciales de España. La Diputación pretendía evitar el método de levas que el jefe político superior disponía, que en su opinión era arbitrario y expuesto a la aplicación de abusos; que estaban en contrariedad absoluta con el sistema constitucional. Con desacato, el jefe político superior ordenó realizar la leva en la capital, que ocasionó notable malestar del ayuntamiento (Herrejón Peredo, 2007: 298). ${ }^{22}$

El conde del Venadito respaldó sus disposiciones sobre el control y organización del ejército, en las normas liberales de las Instrucciones para el gobierno interior de las provincias (Cap. III, art. V y XX); que establecían que el cargo de jefe político solamente podría reunirse con el de comandante de armas en cada provincia, cuando se encontrara amenazada la tranquilidad interior y exterior del Estado. Consideraba que éste era el caso ante las amenazas del Ejército Trigarante (Cortes Generales y Extraordinarias, 1811, Tomo IV: 119).

Así como la Diputación reprobó la disposición del conde del Venadito de suspender la libertad de imprenta, también lo hizo el ayuntamiento de la ciudad de México; pero además agregó a su condena otras medidas que había ordenado el jefe político superior en su afán de detener la insurrección de Iturbide.

Condenó la determinación contra la libertad de imprenta, los bandos de requisición de caballos, armas y monturas, y la rigurosa leva que se estaba practicando con violencia y mano armada. Estimó que estas disposiciones eran opuestas a los procedimientos dictados en la constitución, porque atacaban el objetivo esencial, que era respetar la libertad individual y las propiedades (Herrejón Peredo, 2007: 358-360). ${ }^{23}$ En defensa de lo ocurrido en la capital y apoyando la posición del ayuntamiento, la Diputación escribió al jefe político:

22 Sesión 74, 3 de abril de 1821.

23 Sesión 8ạ, 26 junio 1821. 
Instruida la diputación que en esta capital se está haciendo leva indistintamente por partidas militares. Tomo en consideración que el método con que se verifica ataca directamente la libertad individual, objeto primero de nuestra constitución como se tiene manifestado al virrey, con fecha 3 de abril último, en el expediente instruido sobre formación de milicia nacional local de esta capital y provisión de reemplazos para su regimiento de infantería provincial; y en cumplimiento de su deber, acordó se haga presente esta observación, solicitando saber para gobierno de esta junta si dimana la providencia de su superioridad o de abuso de algunos subalternos (Herrejón Peredo, 2007: 352). ${ }^{24}$

La Diputación basaba su rechazo a los métodos violentos para realizar la leva que ordenó el jefe político superior también en la Instrucción para el Gobierno Económico Político de las Provincias (art. $3^{\circ}$ del capítulo $2^{\circ}$ ), donde se establecía que las diputaciones provinciales resolverían todas las dudas y quejas que se suscitaran en los pueblos sobre el reclutamiento o reemplazo para el ejército.

A mediados de septiembre, Francisco Novella pretendió conseguir la aprobación de la Diputación Provincial y del ayuntamiento constitucional de la ciudad de México a su imprevista decisión-después de su anterior negativa- de reconocer a Juan O’Donojú como legítimo Jefe Político Superior de Nueva España. Los reunió en Palacio Nacional y les comunicó las tres conclusiones a las que llegó después de una entrevista que sostuvo con O'Donojú: quedó satisfecho con los despachos originales que presentó O’Donojú, por lo cual lo reconocía; había un inconveniente en dar a conocer su reconocimiento, porque él debía cesar en sus funciones y no había una autoridad que estuviera al frente del gobierno y del mando militar, hasta que O’Donojú entrara a la capital; y estaban dispuestos a reconocer y obedecer a O’Donojú los cuerpos expedicionarios, pero solicitaba que se le ga-

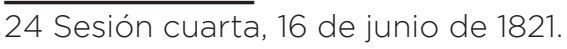

rantizara libertad y no fuera "amancillado o ultrajado el honor militar" (Herrejón Peredo, 2007: 387-389). ${ }^{25}$

La única observación fue del alcalde primero, quien propuso que en los Tratados de Córdoba se repitiera el artículo del Plan de Iguala relativo a respetar las propiedades individuales. Acordaron la Diputación y el ayuntamiento dejar inscrito en el acta de sesiones de la Diputación que

Francisco Novella se ha manejado con el mayor tino, prudencia e integridad, evitando en toda ocasión perjudicar a los ciudadanos en sus personas e intereses, cuando en el acaloramiento de las pasiones se presentaban denuncias contra muchos, y procurando por medio de la dulzura y buen trato con todos sin excepción, adquiriese el aprecio, como ciertamente se lo ha adquirido, de ambas corporaciones (Herrejón Peredo, 2007: 387-389). ${ }^{26}$

El respaldo de la Diputación Provincial y del ayuntamiento de la ciudad de México a Novella fue decisivo para el empoderamiento de Juan O’Donojú en todo el antiguo virreinato; abriendo el paso a la entrada triunfal del Ejército Trigarante a la capital y con ello la firma del Acta de Independencia.

La Diputación Provincial y el Ayuntamiento de la ciudad de México también estuvieron actuando conjuntamente en la preparación de la entrada a la capital de Juan O’Donojú, Capitán General y Jefe Político Superior, y de Agustín de Iturbide, primer jefe del Ejército Trigarante, mediante un bando previniendo las demostraciones públicas y encargando el buen orden y tranquilidad públicas de los habitantes. El coronel José Ignacio Ormaechea, alcalde primero del ayuntamiento constitucional, precisó a la Diputación que la Instrucción para el Gobierno Económico Político de las Provincias encargaba a los ayuntamientos las medidas generales de buen gobierno, que debían tomarse para asegurar y proteger a las per-

25 Sesión 19, acta celebrada en la mañana del 14 de septiembre de 1821.

26 Sesión 19, acta celebrada en la mañana del 14 de septiembre de 1821. 
sonas y sus bienes (Cap. I, art X) (Herrejón Peredo, 2007: 392-393). ${ }^{27}$

El tipo de relación que tuvo la Diputación Provincial de Nueva España con los demás ayuntamientos respondía a otras inquietudes e intereses propios de cada localidad. En 1821 existía una ruptura gubernamental entre los poderes provinciales (jefe político superior y Diputación) y de éstos con la metrópoli. Los postulados de la Constitución liberal ayudaron a resolver la ingobernabilidad local, con la propagación de ayuntamientos, la elección indirecta de sus integrantes y su fervor por administrar y gobernar las localidades bajo su jurisdicción. Presentamos algunas de las peticiones de los ayuntamientos a la Diputación Provincial de Nueva España, que reflejaba su lamentable situación económica y social. Los ayuntamientos se enfrentaron principalmente a tres acontecimientos relacionados con el avance de los Trigarantes y los actos militares para contenerlo, que provocaban dudas e inconformidad y que compartieron con la Diputación Provincial: las contribuciones y pagos en especie que demandaban los comandantes militares del virreinato y los Trigarantes, la utilización de las contribuciones militares en gastos municipales y los abusos de poder de los comandantes.

De acuerdo con Christon Archer, en las zonas realistas los comandantes regionales cobraban contribuciones militares o impuestos sobre los bienes de los habitantes y muchos terratenientes, mineros, comerciantes y artesanos quedaron en la pobreza (2010: 155-156). Las aportaciones en dinero y especie que eran requeridos a los pueblos provocaron inconformidad en sus habitantes. Por ejemplo, Miguel Torres visitó los pueblos de Temascaltepec para obtener recursos para sus fuerzas, pero el ayuntamiento se negó a cumplir la disposición. Para resolver la negativa de los pueblos, Iturbide ordenó a sus oficiales que dispusieran de las alcabalas, diezmos y de otras contribuciones de los ayuntamientos, ocasionando fricciones, como en Sultepec y Temascaltepec (Ortiz Escamilla, 1992: 16-168).

27 Sesión 23 extraordinaria, 25 de septiembre de 1821.
En los primeros meses de 1821, los pueblos del partido de Metepec fueron afectados por las constantes peticiones que hicieron diferentes oficiales a los ayuntamientos para embargar todas las mulas y burros de los vecinos, para cobrar las contribuciones y para alistar las milicias nacionales. Ante ello, en alguna ocasión un ayuntamiento intentó negarse recibiendo en contestación: "Remita cuantos carros y burros aparejados puedan recolectar sin que valga excusa ni pretexto, ya que de lo contrario, los tomaremos a la fuerza haciendo responsable al alcalde de dicha corporación de los perjuicios que sucedan al vecindario" (Archivo General del Estado de México, 1978: 42-45). ${ }^{28}$

El ayuntamiento de Monte Bajo expresó a la Diputación que no eran necesarias las tropas de los patriotas; solicitaba que se quitaran porque obligaba a los vecinos a hacer un gasto innecesario, proponiendo que esa fuerza armada se organizara solamente cuando se necesitara. ${ }^{29}$ En el caso que no pudiera quitarse se disminuyera su número y fueran pagados por el ayuntamiento. También hacía otras solicitudes para disminuir la pobreza de los habitantes provocada por las contribuciones: que se quitara la pensión que pagaban los habitantes por el consumo de maíz por recaía en los pobres; que no se obligara a los pueblos a proporcionar mozos que dieran servicio gratuito al comandante de armas y que se quitara la pensión de un octavo en cada carga de leña y carbón que se estuviera cobrando como parte de la pensión militar. Se acordó, de acuerdo con los principios constitucionales,

\section{Documento 81.}

29 El "Reglamento provisional para la milicia nacional en las provincias de Ultramar" publicado en Madrid el 24 de octubre de 1820 exponía que "esta milicia se componía de todos los cuerpos o compañías urbanas y demás de esta clase, que con el nombre de Realistas, Patriotas u otro semejante existieren en las provincias ultramarinas [...] la Milicia entendida como fuerza de ciudadanos mandados por ciudadanos erigida contra los enemigos de nuestra independencia y libertad civil y para la defensa de la Monarquía. La intervención de americanos (y particularmente oriundos de la Nueva España) en este reglamento resalta la importancia que éstos adjudicaban a los cuerpos en los que pretendía fundarse la fuerza miliciana ultramarina" (Moreno Gutiérrez, 2016: 99-100). 
notificar al ayuntamiento que no consintiera que vecino alguno fuera obligado a servir involuntaria y personalmente sin ser pagados sus servicios; y que lo mismo se advertiría al comandante militar (Herrejón Peredo, 2007: 67). ${ }^{30}$

Los ayuntamientos hicieron constante mención de la afectación que les ocasionaba a los pueblos mantener las contribuciones para los patriotas o realistas o milicia nacional. El ayuntamiento de Iguala resistió pagar la contribución de patriotas; el alcalde de Almoloya, a nombre de su ayuntamiento, solicitó que se le permitiera usar el sobrante que quedaba mensualmente de la contribución para pago de tropas, con el fin de crear y fomentar una escuela de primeras letras y concluir las casas consistoriales. No se autorizó incitándolo a proponer arbitrios. También el ayuntamiento de Pueblo Viejo pretendió aplicar un sobrante de dinero que quedó de los patriotas suprimidos y utilizar el cuartel de éstos para casas consistoriales (Herrejón Peredo, 2007: 206, 214, 215 y 244). ${ }^{31}$

Un caso similar presentó el ayuntamiento de San Miguel Tilapa, porque la "contribución patriótica" que recaudó la aplicó en el mantenimiento de la escuela, casas consistoriales y cárcel. La Diputación acordó se previniera al ayuntamiento porque excedió sus funciones, se dispuso que devolviera a la Junta Patriótica cuanto había cobrado y que propusiera arbitrios equitativos para sus fondos (Herrejón Peredo, 2007: 72). ${ }^{32}$ El ayuntamiento de Petalcingo, jurisdicción de Acatlán, sí solicitó autorización para utilizar la contribución sobrante de la pensión patriótica para gastos municipales. Se acordó que se remitiera al intendente de Puebla, para que formalizara una revisión de cuentas de esa contribución con el teniente coronel correspondiente; al concluirse el informe se dispondría del destino del sobrante (Herrejón Peredo, 2007: 289). ${ }^{33}$

30 Sesión 14, 29 de agosto de 1820.

31 Sesiones 56, 58 y 60 del 30 de enero, 6 y 20 de febrero de 1821.

32 Sesión 16, 5 de septiembre de 1820.

33 Sesión 72, 29 de marzo de 1821.
Los ayuntamientos no lograban reunir suficientes recursos ni para las extraordinarias contribuciones militares ni para su quehacer administrativo; lo que incrementaba las tensiones con el jefe político superior y los comandantes militares. En muchas ocasiones, solventar los gastos de los ayuntamientos dependía de la riqueza de sus miembros para pagar los sueldos de los secretarios y maestros, así como también de la cooperación de la población (obligada o espontánea) para contribuir extraordinariamente en el arreglo de caminos, cárceles y puentes. Estas obras públicas se suspendieron por los escasos recursos, debido a las altas contribuciones destinadas a sostener las tropas del gobierno español.

La Diputación Provincial no pudo solucionar todos los problemas que le expusieron los ayuntamientos; pero cuando estaba en sus atribuciones apoyó sus respuestas en las disposiciones de la constitución liberal. La Diputación recibió varias solicitudes para utilizar la contribución dirigida al mantenimiento de tropas en gastos municipales. Una fue del ayuntamiento de Temascaltepec sobre apropiarse de la cobranza de las pensiones militares y rebajar los sueldos a los realistas (Herrejón Peredo, 2007: 133). ${ }^{34}$ El ayuntamiento de Chapultepec, jurisdicción de Tenango, se quejó del ayuntamiento de Calimaya, donde estaba la cabecera de partido y radicaba el comandante, porque le cobraba la pensión impuesta para las tropas; pero como ya no había tropas, solicitaba que esa contribución fuera utilizada para el mantenimiento de la escuela; la Diputación acordó que al no haber tropas, cesaba la contribución militar, pero para los gastos de la escuela y demás servicios públicos propusiera el ayuntamiento los arbitrios prudentes (Herrejón Peredo, 2007: 134). ${ }^{35}$ El ayuntamiento de Cuautla informó a la Diputación que estaba sosteniendo los gastos de la escuela con los sobrantes de la contribución militar y pedía la aprobación de la instancia superior. Se acordó que se pagara la escuela como proponía el ayun-

34 Sesión 36, 18 noviembre de 1820.

35 Sesión 36, 18 de noviembre de 1820. 
tamiento (Herrejón Peredo, 2007: 289). ${ }^{36} \mathrm{El}$ de Huichapan se negaba a aplicar la pensión que pagaban los vecinos por las semillas de maíz, con el nombre de "contribución de guerra", para que se usara ese dinero en pagar a los maestros de escuela (Herrejón Peredo, 2007: 304). ${ }^{37}$

La Diputación llamó la atención al ayuntamiento de Izúcar para impedir los evidentes abusos que estaba cometiendo al distribuir los fondos que arbitrariamente había colectado y aplicado a los gastos del ayuntamiento. Agregó que tendría que reducir el cobro de las contribuciones que estaba recaudando para el "mantenimiento de los realistas", de acuerdo con lo que dispusiera el jefe político superior. De esta manera, el ayuntamiento formaría un nuevo presupuesto, tanto para el mantenimiento de las tropas como para los indispensables gastos de aquella corporación (Herrejón Peredo, 2007: 194). ${ }^{38}$

Junto con los excesos en las contribuciones para mantenimiento de las tropas, se sumaban otras afectaciones sociales y administrativas, como el manejo de cuentas, la pobreza de los vecinos, la falta de arbitrios, el cobro de la contribución por la compra de maíz y el maltrato de los comandantes a los habitantes exigiendo servicios gratuitos. El ayuntamiento de Zacatlán pidió a la Diputación la reposición de unos fosos y barricadas, así como la aminoración de contribuciones militares. Se mandó averiguar si el ayuntamiento había mandado cegar los fosos y destruir los parapetos sin orden superior. Lo que la Diputación averiguó fue

36 Sesión 72, 29 de marzo de 1821.

37 Sesión 75, 7 de abril de 1821.

38 Sesión 52, 20 de enero de 1821. También se presentaron otras desavenencias entre la Diputación Provincial y los ayuntamientos, como expone Juan Ortiz Escamilla: "Por lo que se refiere a las relaciones entre el Ayuntamiento [de Veracruz] y la Diputación Provincial, tampoco fue color de rosa. Si bien, el cabildo había sido uno de los principales promotores de la Constitución gaditana, no aceptó la injerencia de la Diputación Provincial en los asuntos internos del partido. Se trataba de un enfrentamiento entre la institución más antigua del virreinato y la nueva figura política provincial. $Y$ es que, a pesar de ser un ayuntamiento constitucional, la composición de sus miembros no simpatizaba del todo con los preceptos liberales" (2010: 201) que los vecinos de esa municipalidad tenían "graves miserias" ocasionadas por "la insurrección por haber sido largo tiempo aquel lugar teatro de la guerra que destruyó las fincas y acabó con los ganados" (Herrejón Peredo, 2007: 86-87). ${ }^{39}$

En la investigación se expuso que el ayuntamiento de Zacatlán había realizado "mala inversión de contribuciones y peores cuentas"; se dispuso que las tropas urbanas que mantenían los vecinos fueran las únicas que guarnecieran a Tolantongo. Se acordó que el jefe político superior nombraría un comisionado para que revisara cuentas, cobrando los recursos a los legítimos deudores y evitando obligar a los indios a trabajar contra su voluntad y sin pagarles por su trabajo (Herrejón Peredo, 2007: 87).40

El ayuntamiento de Capulhuac expuso a la Diputación que no podía realizar el pago de la "contribución para realistas" y denunciaba "la opresión en que éstos tienen al pueblo". Interpelaba que era necesario disolver sus milicias nacionales para libertarse de los gravámenes correspondientes. También el ayuntamiento de San Lorenzo Huitzitzilapan pidió que se les liberara de la contribución militar (Herrejón Peredo, 2007: 219). ${ }^{41}$

En algunos casos se solicitó la intervención de los ayuntamientos para actualizar el padrón de vecinos contribuyentes y de acuerdo con éste realizara un cálculo del pago de la milicia. Así, el ayuntamiento de Taxco explicó a la Diputación que si permanecía la fuerza de tropa en aquel punto y por lo tanto el cobro de las contribuciones militares, el comandante debía informarle sobre varios puntos: lo que en ese momento pagaba de contribuciones cada pueblo y vecino, el número de realistas que consideraba necesario para la defensa y un presupuesto mensual de los gastos de la tesorería militar. Necesitaba estos datos para formar y remitir una propuesta del nuevo cobro equitativo de los contribuyentes para la aprobación de la Diputación. Se acordó

39 Sesión 21, 26 de septiembre de 1820.

40 Sesión 21, 26 de septiembre de 1820

41 Sesión 59, 10 febrero de 1821. 
interponer la mediación de la Diputación para que el jefe político superior y capitán general ordenara al comandante militar de Taxco que presentara al ayuntamiento los datos que solicitaba, a fin de que éste propusiera el plan requerido (Herrejón Peredo, 2007: 79). ${ }^{42}$

El control de las contribuciones establecidas en los pueblos para sostener a las fuerzas militares representó uno de los principales motivos de pugna entre ayuntamientos y jefes militares. El argumento principal de defensa de los ayuntamientos fue la pobreza de los pueblos y por eso la imposibilidad de pagar las contribuciones (Moreno Gutiérrez, 2016: 111).

El dinero recaudado no sólo se utilizaba para el mantenimiento de las tropas, sino para la construcción de fortificaciones ordenadas por los comandantes. Las fortificaciones disminuyeron las facultades de los ayuntamientos y acrecentaron el poder de los comandantes; sin ningún beneficio para los pueblos fortificados, al destruirse las milpas y el comercio y aumentar las contribuciones (Archer, 2010: 147).

El ayuntamiento de Puebla expuso a la Diputación los desembolsos que lo obligaba el comandante general militar, para invertirlos en obras de fortificación. En su respuesta señaló los principios liberales expresados en la legislación gaditana sobre la conservación de un orden en los ingresos recaudados por los ayuntamientos y en su empleo restringido a los servicios internos; reprobó que esos ingresos fueran exigidos para la construcción de fortificaciones, que afectaban la vida de los pueblos:

Los fondos que se dan a los ayuntamientos tienen por objeto el cumplimiento de los encargos que le hace la Constitución, explicados con extensión y toda claridad en la Instrucción para el Gobierno Económico, que cualquier otro destino que se les dé, es un abuso y la Diputación Provincial jamás podrá autorizarlo aprobando la distinta inversión que de ellos hiciesen los ayuntamientos; que las obras de fortificación y defensa no están comprendi-

42 Sesión 18, 12 de septiembre de 1820. das en las atribuciones de estos cuerpos, pertenecen a la nación entera, como que en ellas se atiende más bien a la ventaja general del reino que la felicidad particular de cada ciudad o pueblo, y es esto tan cierto que por el contrario los pueblos en particular hacen un sacrificio al bien general cuando se les rodea de fortificaciones y convierte en punto de defensa, pues en este caso quedan expuestos a los horrores del hambre en los asedios, o a los estragos de la cuchilla del vencedor en los asaltos, de que están libres los pueblos abiertos; que el erario público es por consiguiente el que debe sufragar los gastos de esta naturaleza, así como todos los demás cuyo objeto es el bien general del Estado, y todos los individuos de que éste se compone deben contribuir a ellos por los mismos medios y bajo las mismas reglas que están establecidas (Herrejón Peredo, 2007: 358-360). ${ }^{43}$

Se dispuso al ayuntamiento que solicitara al intendente Ramón Gutiérrez del Mazo un documento que avalara los 3000 pesos entregados al comandante para pagar las fortificaciones, a fin de reclamar su pago en la Hacienda provincial y que procurara mejorar con todo el interés y eficacia su relación con el comandante.

Los ayuntamientos tenían la obligación de recolectar las contribuciones para mantener las tropas; sin embargo, algunos vecinos, propietarios y administradores de haciendas se negaron a pagar la contribución para el sostenimiento militar. El dueño de la hacienda de San José el Grande en el partido de Tepeapulco expuso que el ayuntamiento le exigía con dureza la pensión militar que debía su finca y no pretendía pagar. El ayuntamiento de Otumba también reportó el mismo problema: los administradores de las haciendas del señor conde de Tepa y de Ignacio Adalid se negaron a pagar la contribución militar (Herrejón Peredo, 2007: 122-123). ${ }^{44}$

El ayuntamiento de Zempoala manifestó que quienes se negaron a pagar la contribución militar fueron los vecinos, además

43 Sesión octava, 26 de junio de 1821.

44 Sesión 33, 7 de noviembre de 1820. 
ninguno se enlistó a las milicias nacionales (Herrejón Peredo, 2007: 133). ${ }^{45}$

Ayuntamientos, vecinos de los pueblos y hacendados se dirigieron a la Diputación Provincial para exponerle sus quejas contra los comandantes y jefes militares. Los vecinos de Chichotla, del municipio del mismo nombre, describieron los "malos tratamientos que recibían del comandante de armas" (Herrejón Peredo, 2007: 173). ${ }^{46} \mathrm{El}$ ayuntamiento de Cuernavaca mencionó que los abusos se presentaban porque muchos vecinos estaban sirviendo en la tropa y al mismo tiempo contribuyendo para su sostenimiento (Herrejón Peredo, 2007: 7677). ${ }^{47}$ Varios hacendados de la misma zona de Cuernavaca, de la jurisdicción de Yautepec, se quejaron de las "duras providencias del comandante general del sur"; informaron que en consecuencia habían formado en Cuernavaca una junta general de administradores de haciendas como medida de defensa. El comandante instruyó a los administradores de haciendas que pusieran 300 hombres montados, armados y uniformados, cuidando que tuvieran mínimas posibilidades de desertar; que sus jefes serían los mismos administradores, quienes los disciplinarían en la milicia; se mantendrían de las contribuciones establecidas, cobrando a los pueblos las pensiones correspondientes y entre tanto pagarían los administradores de su bolsillo a toda la gente que se les señalaba.

Los hacendados de Yautepec consideraban que la Diputación debía conocer este asunto tomando en cuenta que "la justicia que les asistía” les permitía no conformarse con tales providencias, ya que no encontraban hombres con las cualidades que quería el comandante general y porque carecían de gente para trabajar las fincas. La Diputación les contestó que consideraba "fundadas y racionales las quejas de los hacendados" y dijo que era urgente resolverlas, por lo que le recomendaría al jefe político superior y capitán general que los "terribles aconteci-

45 Sesión 36, 18 noviembre de 1820.

46 Sesión 47, 2 de enero de 1821.

47 Sesión 18, 12 de septiembre de 1820. mientos" exigían un pronto remedio, ya que no concebía que

cada comandante en su punto obre sin tener reglas que lo dirijan, de que exijan pensiones que le acomoden para gastos que él solo sabe, y de que no da cuenta, y de que quiera que todos sean soldados gravando de este modo a unas clases y a unos pueblos más que a otros [...] suplicándole que tomando en consideración los males que se exponen, se sirva presentar a los suplicantes los alivios que las circunstancias permiten, y que sean análogos a la rectitud de su intención, dictando las reglas que juzgue oportuna para el remedio de dichos males (Herrejón Peredo, 2007: 340341). ${ }^{48}$

Un tema importante para los ayuntamientos era saber cuáles eran sus facultades y obligaciones ante la milicia realista, particularmente aquellos que se encontraban conviviendo con tropas del gobierno y con el comandante respectivo. Querían tener la posibilidad de decisión sobre lo que consideraban abusos; sin embargo, la legislación liberal solamente los asignaba como ejecutores de los acuerdos de la Diputación y las órdenes del jefe político superior.

El ayuntamiento de Acapulco solicitaba que le precisaran los límites de sus facultades y las que tenía el jefe militar, para evitar malos entendidos entre las dos autoridades; el mismo ayuntamiento pedía que se declararan exentos todos los vecinos del reemplazo de las tropas veteranas y milicias de artillería e infantería, por la mala situación de los mismos (Herrejón Peredo, 2007: 114). ${ }^{49}$ El ayuntamiento de Texcoco expuso que el coronel Castro impuso contribuciones desiguales a los vecinos, sin tomar en cuenta las opiniones ni la información de esa corporación ni de los interesados, exponiendo que de los 60 hombres de guarnición de infantería y caballería que estaban en su comarca, la mitad eran "inútiles" (Herrejón Peredo, 2007: 216). ${ }^{50}$ Miguel Escami-

48 Sesión 84, 26 de mayo de 1821.

49 Sesión 30, 27 de octubre de 1820

50 Sesión 58, 6 de febrero de 1821. 
Ila, vecino de Tacubaya, se quejaba de que el establecimiento de milicias nacionales había quebrantado el reglamento del ayuntamiento de aquel lugar (Herrejón Peredo, 2007: 126). ${ }^{51}$ La representación del ayuntamiento de Miacatlán se lamentó de la conducta de los comandantes, por la dureza con que estaban cobrando las contribuciones militares; el ayuntamiento informó que algunos hombres se suicidaron por no poder aguantar "el cruel trato y las amenazas de los recaudadores" (Archer, 2010: 156; Herrejón Peredo, 2007: 128). ${ }^{52}$ El ayuntamiento de Amealco se quejó de las providencias que tomó el comandante de San Juan del Río sobre las tropas, solicitando permiso para establecer milicia nacional (Herrejón Peredo, 2007: 338). ${ }^{53}$

La Diputación Provincial calificó "con asombro y compasión" la situación de los pueblos de San Lorenzo, San Esteban, San Gregorio y San Ambrosio, del curato de Achiotepec, "como triste y dolorosa, debido a la servidumbre que sufrían", por los procedimientos excesivos del comandante teniente coronel José María Lubián y de un hermano. En su respuesta a estos pueblos, expresó que "no puede esta diputación, aunque lo desea, prestarles el remedio, pero bien satisfecha de que lo conseguirán de la clemente, benéfica y justificada mano del jefe político superior y capitán general" (Herrejón Peredo, 2007: 286). ${ }^{54}$

Pocos ayuntamientos solicitaron el establecimiento de milicias nacionales, por lo oneroso que les representaba a los vecinos, a pesar de haber sido planeada por el liberalismo gaditano como "principal garante del gobierno constitucional”, particularmente desde 1820 (Moreno Gutiérrez, 2016: 89). Estos ayuntamientos fueron Zinacantepec, San Lorenzo Chaucingo, Calpulalpan, San Felipe Ixtacuixtla, Amealco y Zumpango de la Laguna (Herrejón Peredo, 2007: 131, 173, 338 y 342). ${ }^{55}$

51 Sesión 34, 11 de noviembre de 1820.

52 Sesión 34, 11 de noviembre de 1820.

53 Sesión 84, 26 de mayo de 1821.

54 Sesión 72, 29 de marzo de 1821.

55 Sesión 35, 14 de noviembre de 1820; sesión 47, 2 de enero de 1821; sesión 84, 26 de mayo de 1821; sesión
Aunque la Diputación tuvo información por parte de los ayuntamientos de individuos o grupos de personas que se manifestaban contra el gobierno de la monarquía hispana, de los que se sumaban a los grupos independentistas y de los que establecían medidas de defensa local, fueron pocos casos. Uno de ellos se presentó en Querétaro, cuyo ayuntamiento se dirigió a la Diputación Provincial para cuestionar la conducta del reverendo Gutiérrez, padre provisional de franciscanos de la misma ciudad, por haber detenido la imagen de María Santísima en el convento de Clarisas, provocando la alteración de la tranquilidad pública de los ciudadanos, dando lugar a agravios contra la autoridad civil, con "ignominia de las virtudes monacales". La Diputación expuso que, dado que se podían ocasionar funestos resultados de alteración a la tranquilidad, en las delicadas circunstancias sociales en que se vivía por los levantamientos militares convenía la unión de las autoridades eclesiásticas y civiles para la conservación del orden público y la fraternidad recomendada por los gobiernos a los pueblos y a los vecinos.

Recomendaba que las autoridades respectivas, eclesiásticas y civiles de la ciudad de Querétaro, acordaran con la militar su proceder, para averiguar quiénes eran los autores de los pasquines y proclamas que se fijaron en las esquinas de las calles de aquella ciudad, que instigaron al pueblo a formar "reuniones peligrosas" en las calles y plazas, so pretexto de venerar a la imagen religiosa de María Santísima. La Diputación precisó "que el ayuntamiento y comandante militar redoblen su vigilancia con respecto a la seguridad, quietud y tranquilidad de los ciudadanos, auxiliándose mutuamente unas y otras autoridades en las providencias que juzguen convenientes para contener y co-

85, 29 de mayo de 1821. Respecto a las milicias nacionales, "sólo se establecerá la Milicia Nacional local en las capitales de provincia y de partido, y en los demás pueblos cuyo ayuntamiento lo pidan". Esta disposición se tradujo, en la Nueva España, en que las cabeceras de partido simplemente debían avisar la formación de sus milicias, mientras que el resto de ayuntamientos debía pedir autorización al gobierno a través de su respectivo intendente (Moreno Gutiérrez, 2016: 95). 
rregir a los perturbadores del orden público, con arreglo a la Constitución y las leyes" (Herrejón Peredo, 2007: 222-224).56

Otros ayuntamientos se vieron afectados por el rompimiento de la tranquilidad pública: el alcalde de Oaxtepec, jurisdicción de Cuernavaca, informó sobre la falta de acatamiento a sus órdenes en aquel vecindario (Herrejón Peredo, 2007: 269); ${ }^{57}$ el alcalde de Tecamac participó que el ayuntamiento se encontraba sin secretario por haber tomado el "partido de la independencia" (Herrejón Peredo, 2007: 354);58 el ayuntamiento de Puebla acompañó su informe con la proclama que publicó, exhortando a aquellos habitantes al cumplimiento de sus deberes como ciudadanos respetuosos del gobierno para que no se incorporaran a los grupos Trigarantes (Herrejón Peredo, 2007: 272); ${ }^{59}$ el alcalde de Tulancingo informó haber utilizado varios fondos municipales para fortificar aquel pueblo para su defensa de las tropas trigarantes, por lo que solicitaba nuevos arbitrios para cumplir con los servicios locales (Herrejón Peredo, 2007: 279). ${ }^{60}$

Otra pesadumbre que tuvieron los vecinos fueron los incendios provocados por los trigarantes; ante ello, el ayuntamiento de San Salvador el Verde expuso la necesidad que tenía de reparar las casas consistoriales, la cárcel y la escuela de primeras letras que fueron incendiadas por "los rebeldes"; además, sus fondos municipales no podían solventar el pago de dotación del maestro, del secretario y del alcalde; describía el estado ruinoso de las tarjeas de agua, de tres puentes y de los caminos reales. Para mejorar la situación solicitó que la Diputación le autorizara el acuerdo que tuvo con los vecinos y hacendados, para que pagaran "moderadas pensiones" (Herrejón Peredo, 2007: 283284). ${ }^{61}$

El ayuntamiento de Veracruz expresó las notables afectaciones sufridas por los vecinos, por lo que solicitó a la Diputación que

56 Sesión 13, 13 de febrero de 1821.

57 Sesión 68, 10 de marzo de 1821.

58 Sesión quinta, 19 de junio de 1821.

59 Sesión 69, 13 de marzo de 1821.

60 Sesión 70, 17 de marzo de 1821.

61 Sesión 71, 20 de marzo de 1821. intercediera con el jefe político superior y capitán militar a fin de que le mandara tropas para la defensa de aquel puerto, que estaba amenazado por el enemigo. Le comentó que estaba interceptada la correspondencia, que necesitaba su aprobación para las erogaciones de gastos de propios y arbitrios que fueran precisos en las críticas circunstancias en la defensa de la plaza. Se acordó que no podía delegar sus facultades, pero el ayuntamiento no necesitaba de delegación alguna para el ejercicio de sus atribuciones y para auxiliar con sus caudales al gobierno en extremas necesidades; sólo le recomendaba obrar con la debida "prudencia y economía” (Herrejón Peredo, 2007: 313). 62

La relación de la Diputación Provincial de Nueva España con los ayuntamientos estuvo apegada a los principios liberales de la Constitución y de la Instrucción para el Gobierno Económico Político de las Provincias. Ambas instituciones se desempeñaron con continuidad en su gobierno y administración permitiendo mínimos elementos de gobernabilidad de la importante provincia (particularmente las decisiones fusionadas entre la Diputación y el ayuntamiento de la ciudad de México). Sus actos y decisiones estuvieron impregnados del ambiente de guerra que rodeaba los meses previos a la culminación del movimiento de Independencia; influyeron de manera positiva en la mayoría de los asuntos propios del desencadenamiento de la consumación de la Independencia, al negarse a pagar contribuciones para las tropas, al usar esas contribuciones en servicios y en obras municipales, al pretender nulificar las disposiciones de los comandantes. Fueron efectos conscientes en la Diputación y el ayuntamiento de la ciudad de México utilizando los ideales liberales constitucionales; en cambio, en los ayuntamientos de localidades rurales fueron actos de supervivencia, de defensa ante los atropellos a las corporaciones y a los vecinos.

62 Sesión 77, 26 de abril de 1821 


\section{Consideraciones finales}

Si consideramos el proceder de dos instituciones, la Diputación provincial y los ayuntamientos, en la Nueva España podemos reconocer que la aplicación que hicieron de la Constitución de la Monarquía Española, en la segunda etapa en la que estuvo en vigor entre 1820 y 1821, fue significativa en la consumación de la Independencia de México. Así se aprecia en las actividades de gobierno y administración desempeñadas por la Diputación, particularmente en su relación con el jefe político superior y capitán general y con los ayuntamientos que no estaban controlados por el Ejército Trigarante.

La Diputación Provincial y los ayuntamientos siguieron trabajando durante los meses de expansión y consolidación de ese Ejército. Hubo momentos cruciales en su funcionamiento, particularmente del ayuntamiento de la Ciudad de México y de la Diputación, cuando se opusieron abiertamente a la dimisión del conde del Venadito y la designación de Francisco Novella, por considerarlas ilegales al no obedecer los dictados constitucionales. Así también defendieron la libertad de imprenta y reprobaron los abusos en las tácticas de leva y la incautación ilegal de la propiedad privada; actos anticonstitucionales que ordenaba el jefe político superior, para frenar el avance de los trigarantes.

La provincia de Nueva España estuvo afectada por hechos bélicos, ocasionados por el enfrentamiento de los trigarantes con las fuerzas militares del gobierno monárquico, representado por el jefe político superior, quien desplegaba tropas, imponía diversas contribuciones para mantenerlas y aprobaba medidas antiliberales tratando de controlar la sublevación social, como las fortificaciones de pueblos. Esas disposiciones provocaron malestar entre las autoridades provinciales y los ayuntamientos, ya que trastornaba sus funciones y atribuciones de gobierno e incrementaba la pobreza entre los vecinos de los pueblos por las constantes contribuciones militares; además, vieron afectada su libertad y su situación económi- ca por los abusos de poder de los comandantes.

Era tal el malestar de la Diputación Provincial por los 10 años de guerra y por la falta de observancia de las disposiciones constitucionales por parte del jefe político superior y capitán general y por los comandantes, que cuando tuvo la oportunidad de expresar su opinión sobre los Tratados de Córdoba, declaró su apoyo porque representaba el fin de las constantes afectaciones sociales ocasionadas por la guerra y por las recientes medidas tomadas por el jefe político superior.

El régimen constitucional asimilado por autoridades provinciales y ayuntamientos cuestionó algunas prácticas que trató de mantener la monarquía, porque trasgredían los derechos liberales e impedían el ejercicio de gobierno. No porque comulgaran totalmente con los nuevos preceptos liberales que trataban de centralizar su proceder, sino porque esas prácticas afectaban el orden social y político que anhelaban construir. Los ayuntamientos actuaban como corporaciones que atendían el bienestar del conjunto de los habitantes, particularmente aquéllos que estaban situados en pueblos. Sus consultas y solicitudes a la Diputación se remitieron a la afectación que se estaba haciendo a los vecinos y a la administración y al buen gobierno de su jurisdicción; proponiendo soluciones diversas, algunas veces apegados a la norma y otras con decisiones propias del bien común. Fueron expresiones iniciales de la combinación de liberalismo y colectivismo, presentes en todo el siglo XIX. De esta manera, participaron la Diputación y los ayuntamientos de Nueva España como dos instituciones destinadas al gobierno provincial y local, que no apoyaron las medidas represivas impuestas para contener el avance del Ejército Trigarante; con ello favorecieron este avance hasta su entrada triunfante a la ciudad de México, el 27 de septiembre de 1821, consumando la Independencia.

Estudiar las reacciones y las afectaciones de los ayuntamientos constitucionales y de las diputaciones provinciales en la últi- 
ma etapa del movimiento de Independencia permite una mirada complementaria a la lucha civil impulsada por Agustín de Iturbide. La vida social y política local influyó directa e indirectamente en el proceso que culminó con el anhelo ampliamente perseguido por los trigarantes.

\section{Fuentes Consultadas}

Archer, Christon (2010), "Historia de la guerra: la trayectoria de la historia militar en la época de la independencia de Nueva España", en Alfredo Ávila y Virginia Guedea (coords.), La independencia de México: temas e interpretaciones recientes, Ciudad de México, UNAM, pp. 145-162.

Archivo General del Estado de México (1978), Archivo General del Estado de México. Catálogo y sintesis de documentos manuscritos relativos a pueblos del estado de México, 1542-1823, Introducción de José Luis Alanís Boyso, Toluca, Oficialía Mayor de Gobierno.

Baranda, Marta y García, Lía (comps.) (1987), Estado de México. Textos de su historia, Ciudad de México, Instituto Mora/ Gobierno del Estado de México, 2 vols.

Benson, Nettie Lee (1994), La diputación provincial y el federalismo mexicano, Ciudad de México, El Colegio de México/Universidad Autónoma de México.

Cortes Generales y Extraordinarias (1811), Colección de los Decretos y Órdenes que han expedido las Cortes Generales y Extraordinarias, Tomos II y IV, Cádiz, Imprenta Real.

Chust Calero, Manuel (2007), "La revolución municipal, 1810-1823", en Juan Ortiz Escamilla y José Antonio Serrano Ortega (eds.), Ayuntamientos y liberalismo gaditano en México, Zamora, El Colegio de Michoacán/Universidad Veracruzana, pp. 19-54.

Del Arenal Fenochio, Jaime (2010), Un modo de ser libres. Independencia y Constitución en México (1816-1822), Ciudad de
México, Instituto de Estudios Históricos de las Revoluciones de México.

Del Arenal Fenochio, Jaime (2002), Un modo de ser libre. Independencia y Constitución en México (1816-1822), Zamora, El Colegio de Michoacán/INEHRM.

Frasquet, Ivana (2010), Las caras del águila. Del liberalismo gaditano a la república federal mexicana, 1820-1824, Castellón y Xalapa, Universitat Jaume I/Universidad Veracruzana.

Guedea, Virginia (1992), En busca de un gobierno alterno: los Guadalupes de México, Ciudad de México, Universidad Autónoma de México.

Hamnett, Brian R. (1990), Raíces de la insurgencia en México. Historia regional 1750-1824, trad. de Agustín Bárcena, Ciudad de México, Fondo de Cultura Económica.

Herrejón Peredo, Carlos (2007), La Diputación Provincial de Nueva España. Actas de sesiones, 1820-1821, prólogo, estudio Introductorio y sumario de Carlos Herrejón Peredo, Ciudad de México, Instituto Mora/El Colegio de Michoacán.

Herrejón Peredo, Carlos (1988), "La Diputación Provincial de Nueva España”, en María Teresa Jarquín Ortega (coord.), Temas de Historia Mexiquense, Toluca, H. Ayuntamiento Constitucional de Toluca/El Colegio Mexiquense, A.C., pp. 195-218.

Lemoine, Ernesto (1985), "¿Consumación o contradicción de 1810?", Secuencias. Revista de historia y ciencias sociales, núm. 1, Ciudad de México, Instituto Mora, pp. 25-35.

Luna Ramos, José Alejandro; González Oropeza, Manuel; Paoli Bolio, Francisco José y Barragán Barragán, José (2012), Constitución Política de la Monarquía Española, Cádiz 1812, Ciudad de México, Tribunal Superior del Poder Judicial de la Federación. 
Moreno Gutiérrez, Rodrigo (2016), La Trigarancia. Fuerzas armadas en la consumación de independencia: Nueva España, 1820-1821, Ciudad de México, Universidad Nacional Autónoma de México/Fideicomiso Felipe Teixidor y Monserrat Alfau de Teixidor.

Ortiz Escamilla, Juan (2014), Guerra y gobierno. Los pueblos y la Independencia de México: 1808-1825, Ciudad de México, El Colegio de México/Instituto de Investigaciones Dr. José María Luis Mora.

Ortiz Escamilla, Juan (2010), El teatro de la guerra: Veracruz, 1750-1825, Xapala, Universidad Veracruzana/Universitat Jaume I.

Ortiz Escamilla, Juan (2008) "Entre la lealtad y el patriotismo. Los criollos al poder", en Brian Connaughton, Carlos Illanes y Sonia Pérez, Construcción de la legitimidad política en México, Ciudad de México, El Colegio de Michoacán/ UAM, pp. 107-126.

Ortiz Escamilla, Juan (1997), Guerra y Gobierno. Los pueblos y la independencia de México, Sevilla, Instituto Mora/ El Colegio de México/Universidad Internacional de Andalucía/Universidad de Sevilla.

Ortiz Escamilla, Juan (1992), "El ejercicio del poder durante la guerra de Independencia en México, 1810-1823", Tesis de doctorado en Historia, El Colegio de México, Ciudad de México.

Pérez Garzón, Juan Sisinio (2007), Las Cortes de Cádiz. El nacimiento de la nación liberal (1808-1814), Madrid, Editorial Síntesis.

Robertson, William Spence (2012), Iturbide de México, traducción, introducción y notas de Rafael Estrada Sámano, presentación de Jaime del Arenal Fenochio, Ciudad de México, Fondo de Cultura Económica.

Rodríguez, Jaime (2009), "Nosotros somos los verdaderos españoles". La transi- ción de la Nueva España de un reino de la Monarquía Española a la República Federal de México, 1808-1824, 2.v., Zamora, México, El Colegio de Michoacán/Instituto Mora.

Rodríguez, Jaime E. (2007), "Las instituciones gaditanas en Nueva España, 18121814", Anuario de Historia Regional y de las Fronteras, 12 (1), Bucaramanga, Universidad Industrial de Santander, pp. 363-384.

Salinas Sandoval, María del Carmen (2011), "Ayuntamientos y Diputación Provincial de México (1821-1823)", en María del Carmen Salinas Sandoval, Diana Birrichaga Gardida y Antonio Escobar Ohmstede (coords.), Poder y gobierno local en México 1808-1857, Zinacantepec, El Colegio Mexiquense, A.C./ El Colegio de Michoacán/Universidad Autónoma del Estado de México, pp. 77-104.

Salinas Sandoval, María del Carmen (2007), "Ayuntamientos en el Estado de México, 1812-1827. Procesos de adaptación entre el liberalismo y el Antiguo Régimen", en Juan Ortiz Escamilla y José Antonio Serrano Ortega (eds.), Ayuntamientos y liberalismo gaditano en México, Zamora, El Colegio de Michoacán/Universidad Veracruzana, pp. 369-410.

Serrano Ortega, José Antonio (2017), "Instituciones artificiales, instituciones naturales. Diputaciones provinciales, Ayuntamientos capitales y Audiencias. Nueva España y México, 1820-1822", Historia Mexicana, 67 (1), Ciudad de México, El Colegio de México, pp. 169-231.

Serrano Ortega, José Antonio (2014), "Los subordinados gaditanos. Diputaciones y ayuntamientos en las provincias de Michoacán y de Occidente, 1820-1823", en Breña, Roberto (ed.), Cádiz a debate: actualidad, contexto y legado, Ciudad de México, El Colegio de México.

Timothy, Anna (1981), La caida del gobierno español en la ciudad de México, Ciudad de México, Fondo de Cultura Económica. 
Villoro, Luis (2000), "La revolución de Independencia", Historia General de México, México, El Colegio de México-Centro de Estudios Históricos, pp. 489-523.

Villoro, Luis (1981), El proceso ideológico de la revolución de independencia, Ciudad de México, Universidad Nacional Autónoma de México.

Recibido: 19 de mayo de 2021. Reenviado: 20 de mayo de 2021. Aceptado: 2 de agosto de 2021.

\section{María del Carmen Salinas Sandoval}

Doctora en Historia por El Colegio de México. Es investigadora adscrita al seminario académico Historia Contemporánea de El Colegio Mexiquense, A.C. Es miembro del Sistema Nacional de Investigadores, nivel II. Sus líneas de investigación son Historia social y política de los municipios, Federalismo decimonónico e Historia de los procesos económicos y sociopolíticos de la modernidad. Entre sus más recientes publicaciones se encuentran, como autora: En busca de la libertad municipal. Toluca 1877-1940, Zinacantepec, El Colegio Mexiquense, A.C. (2018) y El primer federalismo en el Estado de México, 1825-1835, Zinacantepec, El Colegio Mexiquense, A.C. (2014). 